\title{
EXULANT JIŘí HOLÍK A JEHO KONTAKTY S LÉKAŘI V NĚMECKÝCH ZEMÍCH A POBALTÍ
}

\author{
MARIE RYANTOVÁ
}

\section{THE EXILE JIŘí HOLÍK AND HIS CONTACTS WITH PHYSICIANS IN THE GERMAN AND BALTIC LANDS}

This contribution deals with inscriptions made by important physicians in the album amicorum of Jiří Holík (1635-1700/1710?), a Czech convert and exile, originally a Dominican friar, who eventually became well known as author of books on horticulture and pomology. Given the nature of the album and Holík's life, these were probably mainly social meetings whose purpose was not a medical examination or medical consultation. Even so, surviving records from the period of 1673-1697 are a valuable source which testifies to the variety of acquaintances of an interesting personage of Czech exile society.

Keywords: alba amicorum - exile - German Lands - Baltic Lands - physicians - Jiří Holík

DOI: $10.14712 / 23365730.2018 .22$

Jedním ze zajímavých pramenů, označovaných jako ego-dokumenty, jsou bezesporu raně novověké památníky, respektive štambuchy či alba amicorum - knihy malého formátu, vedené převážně na cestách (zejména studijních a kavalírských) a obsahující záznamy nejrůznějších osob. Mezi jejich majiteli a především zapisovateli najdeme nejen studenty, at' již šlechtické či neurozené, a profesory, ale i vojáky, úředníky, maliřské i jiné tovaryše, a dokonce také ženy - na základě čehož lze stanovit alespoň základní typologii památníků. Právě díky svému značnému rozšíření, funkci a mnohostrannému obsahu slouží dnes památníky jako významný interdisciplinární pramen: dokládají cesty a kontakty svých majitelů, sebeprezentaci jak jich, tak jednotlivých zapisovatelů, vypovídají o jejich mentalitě, jsou cenným zdrojem informací pro heraldiku, genealogii, emblematiku, dějiny umění a ikonografii, kodikologii i dějiny knižní kultury, pro dějiny vzdělání, cestování, hudby, vědy, vojenství, módy, diplomacie, sexuality, filologie či literární vědy. ${ }^{1}$ „Zlatým věkem“

1 Z velmi početné literatury k památníkům alespoň Peter AmElung, Die Stammbücher des 17. Jahrhunderts als Quelle der Kultur- und Kunstgeschichte, in: Heinrich Geissler (ed.), Zeichnung in Deutschland. Deutsche Zeichner 1540-1640. Staatsgalerie Stuttgart, Graphische Sammlung: Katalog zur Ausstellung 1. 12.1979 17. 2. 1980, Bd. 2, 1980, s. 211-222; Wolfgang KLose (ed.), Stammbücher des 16. Jahrhunderts (Vorträge gehalten anläßlich eines Arbeitsgespräches vom 18. bis 20. Juni 1986 in der Herzog August Bibliothek), Wiesbaden 1989 (= Wolfenbütteler Forschungen 42); Werner Wilhelm Schnabel, Das Stammbuch. Konstitution und Geschichte einer textsortenbezogenen Sammelform bis ins erste Drittel des 18. Jahrhunderts, Tübingen 2003; česky Marie RyantovÁ, Památniky, aneb štambuchy, to jest alba amicorum. Kulturně historický fenomén raného novověku, České Budějovice 2007. 
existence památníků je sice období druhé poloviny 16 . století, byly však intenzivně pořizovány a vedeny až do počátku 18 . století a od jeho konce pak nastává další rozvoj jejich používání, spojený s proměnou jejich forem.

Přestože samotné památníkové záznamy jsou obvykle velmi stručné a mívají specifickou podobu, lze díky nim doložit nejen průběh cest, ale zvláště navázání různých kontaktů a vytváření sítě vztahů mezi jednotlivými osobnostmi. Otázkou prìtom samozřejmě zůstává intenzita navázaných kontaktů, respektive úvahy, nakolik přesáhly pouhou žádost o záznam do památníku (odpovídající i dnešnímu získávání autogramů jejich sběrateli); vzhledem $\mathrm{k}$ tomu, že záznam byl připojován na základě osobního setkání, lze snad předpokládat alespoň návštěvu př́slušné osoby a krátký rozhovor.

Jedním ze zajímavých památníků bohemikálního charakteru je nepochybně také „album“ českého exulanta Jiř́ho Holíka, dochované dnes již jen jako torzo v podobě jednotlivých listů, které však přesto obsahují úctyhodný počet 226 záznamů z mnoha různých lokalit z let 1672 až 1698 a dokládají tak pestré osudy svého majitele. ${ }^{2}$ Jiří Holík (1635-1700/1710?) původně pocházel z nekatolické rodiny z okolí Řiccan u Prahy, v deseti letech jej však odvedli jezuité, u nichž získal vzdělání. Poté vstoupil do dominikánského rádu a byl vysvěcen na kněze. Podle svého svědectví působil i jako inkvizitor a podílel se na vyhledávání nekatolických knih, postupně se však rozhodl odejít za hranice a stát se kazatelem českých exulantů. Po prvním nezdařeném pokusu byl sice uvězněn, ale v záŕí 1666 se mu skutečně podařilo dostat se do Žitavy a vzápětí konvertoval k luterství. Přestože jeho snahy o jmenování kazatelem nebyly zpočátku úspěšné, podařilo se mu získat př́zeň knížete Augusta von Sachsen-Weißenfels, který měl na svém území po skončené třicetileté válce mnoho zpustlých vsí, a proto se rozhodl na své panství pozvat exulanty a dát svolení k založení jejich kolonie; současně podpořil Jiřího Holíka a umožnil mu další studium ve Wittenbergu. A tak se někdejší dominikán stal v roce 1669 kazatelem nově vzniklé české exulantské obce v Barby a Wespen u Magdeburgu. Přestože tím dosáhl splnění svého přání a získal vhodné uplatnění, založil dokonce rodinu a jeho život nabyl jasný směr i pevné zakotvení, nesetkal se ve svém působení s úspěchem. Jeho farníci si brzy začali stěžovat, že neplní své povinnosti, a měli výhrady i vůči Holíkovým kázáním, jimž se Holík sice snažil čelit, ale nakonec musel své místo opustit. Při hledání dalšího uplatnění zavítal i do Švédska, kde se údajně pokusil získat prostředky na vydávání knih pro exulanty. Poté se na čas vrátil do Wittenbergu, kde se zapsal na univerzitu a vydal několik silně protikatolicky zaměřených knih, nakonec však zakotvil v tehdy švédské Rize a proslul jako autor mnohokrát vydávaných a oblíbených zahradnických knih, díky nimž se zařadil mezi významné a uznávané osobnosti evropské pomologie 17. století. Již od roku 1673 a zejména počínaje rokem 1683 absolvoval řadu cest, na nichž nejspiše prodával či rozdával své knihy, jejichž prostřed-

2 Staats- und Landesbibliothek Hamburg, Autographensammlung, Cod. in scrinio 62, 66, 68, 70; Cod. Scrin. N. 222, N. 222a. Památník se dochoval v podobě jednotlivých listů rozptýlených v tzv. Uffenbachově-Wolffově sbírce (Tilo Brandis, Die Codices in scrinio der Staats- und Universitätsbibliothek Hamburg, Hamburg 1972, s. 121-125; Konrad Franke, Zacharias Conrad von Uffenbach als Handschriftensammler. Ein Beitrag zur Kulturgeschichte des 16. Jahrhunderts, Archiv für Geschichte des Buchwesens 7, 1967, Sp. 1-208; Börsenblatt für den deutschen Buchhandel 45, 1965, s. 1235-1338; Axel E. WALTER, Privates Sammeln als kulturelle Gedächtnisarbeit: zur Entstehung der uffenbach-wolfschen Briefsammlung im Kontext der Hamburger Bibliotheksgeschichte, Hamburg 2012, s. 227-252); za upozornění na něj vděčím Zdeňku Hojdovi. Celkem je doloženo 226 záznamů od různých osobností z německých zemí i Pobaltí z let 1672-1698, jimž bude věnována samostatná rozsáhlá studie. 
nictvím žádal o podporu; později se během cest věnoval i zahradnické činnosti a získával zkušenosti, které následně zpracoval $\mathrm{v}$ dalších knihách. Jeho rodina přitom zřejmě žila v Rize, kam se Holík vracel (v úvodu své druhé zahradnické knihy Versprochenes Bluhmen- und Küchen-Garten-Büchlein, vydané v Rize roku 1687, připojil věnování dvěma purkmistrům a celkem jedenatřiceti konšelům a vyslovil svi̊j vděk za možnost žít ve městě, $v$ němž nalezl i se svou rodinou druhý domov). $V$ tomto městě snad někdy na počátku 18. století i zemřel. ${ }^{3}$ Na svých cestách se Jiř́i Holík setkával s nejrůznějšími osobnostmi, většinou významnými a proslulými, především pastory a superintendenty, teology, univerzitními profesory a rektory, právníky, kurfiřtskými rady i úředníky. Záznamy v památníku se staly připomínkou těchto setkání. Jednu ze zajímavých skupin zapisovatelů představují také někteř́ lékaři.

Prvním z lékařŭ, zaznamenaným v památníku Jiř́ho Holíka, byl Konrad Viktor Schneider (1614 Bitterfeld - 1680 Wittenberg), doktor medicíny, žák Daniela Sennerta (1572-1637), významný lékař a anatom 17. století, který působil od roku 1638 či 1639 jako profesor lékařství a botaniky na univerzitě ve Wittenbergu. Mnohokrát (v zimních semestrech v letech $1641,1645,1649,1655,1661,1667,1673$ a 1679) byl jejím rektorem a děkanem lékařské fakulty, ale současně zastával i funkci osobního lékaře saského kurfiřta. Jeho hlavním dílem je pětisvazková práce De catarrhis (Wittenberg 1660-1662, 5 svazků), v níž vyvrátil dosud platnou teorii, že se hlen utváŕí v mozku, a navíc objevil nosní sliznici, která po něm dostala název Membrana Schneideria. Významné jsou však i jeho další spisy, vzniklé na základě vlastního pozorování a týkající se anatomie, fyziologie a všeobecné patologie, díky nimž se zařadil mezi nejvýznamnější představitele medicíny 17 . století. ${ }^{4}$ Jeho setkání s Jiřím Holíkem je doloženo 2. dubna 1673 ve Wittenbergu. ${ }^{5}$

3 Marie Ryantová, Konvertita a exulant Jiři Holik - nelehký osud uvnitř $i$ vně ř́du, Folia Historica Bohemica 27/1, 2012, s. 135-154; TÁž, Der Konvertit und Exulant Jiř́ Holik und seine antikatholischen Schriften, Acta Comeniana 49/25, 2011, s. 199-219; тÁž, Z Čech do Žitavy, Budyšína a Wittenbergu. Cesta exulanta Jiřího Holika za uplatnéním protestantského kazatele, in: Navzdory hranici. Migrační procesy na česko-německém pomezí / Trotz der Grenze. Migrationsprozesse im tschechisch-deutschen Grenzgebiet, Plzeň 2013, s. 107-118; TÁž, Jiři Holik: od dominikánského cenzora v Plzni k protestantskému kazateli, in: Lenka Špačková - Jiří Stočes (eds.), Historická dílna IX. Sborník příspěvků přednesených v roce 2014, Plzeň 2015, s. 86-115; TÁž, Zahradničením ke slávě: zahradnické tisky exulanta Jiřiho Holika jako di̊sledek změny jeho literárni činnosti a jejich proměny, in: Jitka Radimská (ed.), Knihy v proměnách času (Opera romanica 16), České Budějovice 2015, s. 262-282, viz <http://www.ff.jcu.cz/documents/10832/171099/OR16+text/021da0e1-665a-407b-a378-028b79f28720> (5. 1. 2018); TÁž, Konvertita a exulant Jiři Holik. Příspěvek $k$ dějinám exilu a problematice konverze v raném novověku, Pelhřimov 2016.

4 Werner Konstantin von ARNSWALDT, Katalog der fürstlich Stolberg-Stolberg schen Leichenpredigten-Sammlung, Bd. 4/1, Leipzig 1935, s. 175-176; Julius PAGEL, Schneider, Konrad Viktor, in: Allgemeine Deutsche Biographie, Bd. 32, Leipzig 1891, s. 134; Schneider, Conrad Victor, in: Johann Heinrich ZedLER, Grosses vollständiges Universal-Lexicon Aller Wissenschaften und Künste, Bd. 35, Leipzig 1743, sl. 538-540; Christian Wilhelm Kestner, Medizinisches Gelehrten-Lexikon, Jena 1740 (reprint Hildesheim - New York - Olms 1971), s. 765; Christian Gottlieb JöcHER, Allgemeines Gelehrten-Lexicon, Darinne die Gelehrten aller Stände sowohl männ-als weiblichen Geschlechts, welche vom Anfange der Welt bis auf die ietzige Zeit gelebt, und sich der gelehrten Welt bekannt gemacht. Nach ihrer Geburt, Leben, merckwürdigen Geschichten, Absterben und Schrifften aus den glaubwürdigsten Scribenten in alphabetischer Ordnung beschrieben werden, Bd. 4, Leipzig 1751, sl. 312; Hans Theodor Kосн, Die Wittenberger Medizinische Fakultät (1502-1652) - Ein biobibliographischer Überblick, in: Stefan Oehmig, Medizin und Sozialwesen in Mitteldeutschland zur Reformationszeit, Leipzig 2007, s. 289-348, tam s. 327.

5 Staats- und Landesbibliothek Hamburg, Autographensammlung, sign. Cod. 70, s. 453, 1462v: „Conradus Victor Schneider, Sereniss[imi] Elect[oris] Saxon[niae] Med[icus] etc.“. 
Rovněž v dubnu $1673^{6}$ se ještě během pobytu ve Wittenbergu Jiří Holík sešel s lékařem a synem již zmíněného Daniela Sennerta Michaelem Sennertem (1615 Wittenberg - 1691 tamtéž), který po studiích ve Wittenbergu (1623), Lipsku (1632) a Altdorfu (1639) získal $\mathrm{v}$ roce 1650 licenciát a doktorát medicíny (1650) a stal se profesorem wittenberské univerzity, po Schneiderově smrti pak jeho nástupcem, v zimních semestrech 1651, 1657, 1669, 1675, 1681 a 1687 navíc působil i jako její rektor. Byl autorem mj. spisů o moru (De peste, 1650), srdci a krvi (De corde, De sanguine, obé 1664) a během svého působení vybudoval soukromé anatomické muzeum, jehož počátky možná položil již jeho otec. ${ }^{7}$

Další setkání s lékařskou kapacitou podle nedatovaného záznamu v památníku nastalo v Rostocku, a to zřejmě v březnu 1674, kdy je Holíkův pobyt v tomto městě doložen. ${ }^{8}$ Tamní profesor Sebastian Wirdig (1613 Torgau - 1687 Rostock) studoval ve Wittenbergu, Lipsku, Königsbergu a Rostocku (1641 už jako magistr) a posléze působil na univerzitě v Dorpatu (dnes Tartu, Estonsko), kde získal v roce 1651 doktorát a stal se profesorem fyziky a lékařství; ještě v roce 1650 a poté 1651 byl rovněž rektorem. V roce 1654 se vrátil do Rostocku, přednášel i chemii a v roce 1655 se zde stal profesorem lékařství. Také on byl, podobně jako K. V. Schneider, současně osobním lékařem, v tomto případě mecklenburského vévody Gustava Adolfa (1633-1695) v Güstrow. Kvůli spisu Nova Medicina spirituum curiosa (Hamburg, 1673), který byl vydáván opakovaně a roku 1707 vyšel v německém překladu, byl podezřelý ze spiritismu a rosenkruciánství a musel se v roce 1684 podrobit zkoumání svých prací ze strany teologické a lékařské fakulty univerzity ve Wittenbergu a vévodské komise, vedené jeho univerzitním kolegou, teologem Michaelem Siriciem (1628-1685). ${ }^{9}$

Je otázkou, zda právě Sebastian Wirdig nepřispěl k tomu, že se Jiří Holík později vydal do Pobaltí. Jeho další zastávkou se ovšem stal Greifswald, kde se mu 20. května 1674 zapsal do památníku ${ }^{10}$ profesor lékařství Christoph Helwig senior (1642 Anklam - 1690 Greifswald). Studoval na univerzitách v Greifswaldu (1656), kde se učil i arabsky, aby

6 Staats- und Landesbibliothek Hamburg, Autographensammlung, sign. Cod. 70, s. 454, 1463v: „Michael Sennertus, D. P. P.“.

7 Viz Sennertus, Michael, in: Johann Heinrich ZedLer, Grosses vollständiges Universal-Lexicon Aller Wissenschafften und Künste, Bd. 37, Leipzig 1743, sl. 77-78; Fritz JuntKe (ed.), Album Academiae Vitebergensis. Jüngere Reihe, 2, 1660-1710, Halle 1952 (Arbeiten aus der Universitäts- und Landesbibliothek Sachsen-Anhalt in Halle a. d. Saale, Band 1), s. 593-594; Elias von Steinmayer, Die Matrikel der Universität Altdorf, Bd. 1-2, Würzburg 1912 (Veröffentlichungen der Gesellschaft für fränkische Geschichte, IV/1), s. 244; H. T. Косн, Die Wittenberger Medizinische Fakultät (1502-1652) - Ein biobibliographischer Überblick.

8 Staats- und Landesbibliothek Hamburg, Autographensammlung, sign. Cod. 70, s. 453, 1462r: „Sebastianus Wirdig, Med[icinae] D]octor], olim in Regia Liv[landiae] Dorpatensi, nunc in illustro Rostochiensi Acad[emia] Prof[esor] et Medicus Ducalis“; další záznam z Rostocku v Holíkově památníku je z března 1674 viz tamtéž, s. 281, 864r (superintendent Henricus Müller, 1631-1675).

9 Viz Axel Wilhelmi, Die Mecklenburgischen Aerzte von den ältesten Zeiten bis zur Gegenwart, Schwerin i. M. 1901, s. 24; Gustav Willgeroth, Die mecklenburgischen Aerzte von den ältesten Zeiten bis zur Gegenwart, Schwerin 1929, s. 236-237; Bernhard WeIssenborn (ed.), Album Academiae Vitebergensis. Jüngere Reihe, 1, 1602-1660, Magdeburg 1934, s. 372; Georg ERLER (ed.), Die jüngere Matrikel der Universität Leipzig 1559-1806, I, Die Immatrikulationen vom Wintersemester 1559 bis zum Sommersemester 1634, Leipzig 1909, s. 518; Adolph Hofmeister, Die Matrikel der Universität Rostock, III, (1611-1694), Rostock 1895, s. 122, 181, 190, 237, 249; Grete Grewolls, Wer war wer in Mecklenburg und Vorpommern. Das Personenlexikon, Rostock 2011, s. 10946. Výsledkem zkoumání byl spis Victrix veritas in censuris theologico-medicis de nova spirituum medicina (1684).

10 Staats- und Landesbibliothek Hamburg, Autographensammlung, sign. Cod. 70, s. 170, 499: „Christophorus Helvigius, Doct[or] et Prof[esor] Medic[inae] ordinar[ius] Acad[emiae] h[oc] t[empore] Rector". 
mohl číst lékařské texty v originále, dále pokračoval ve studiích v Lipsku (1659) a Leidenu. V roce 1663 odcestoval do Londýna, odkud si přivezl cennou sbírku spisů, přes Paříž zamíríil do Itálie (kde pobýval v Padově, Římě a Neapoli) a na konci roku 1665 se dostal do Basileje, kde získal doktorát (1666), a následně se vrátil domů. V roce 1667 se stal profesorem lékařství na univerzitě v Greifswaldu, v letech 1669, 1673, 1678 a 1686 byl zvolen jejím rektorem. Od roku 1664 byl i členem Leopoldiny (Academia Naturae Curiosorum), nejstarší německé přírodovědecko-lékařské společnosti, založené v roce 1652 ve Schweinfurtu a nazvané později podle císaře Leopolda I. Rovněž on se řadil mezi lékaře vládnoucích osob - braniborského ,velkého kurfiřta“ Friedricha Wilhelma (1620-1688) a již zmíněného meklenburského vévody Gustava Adolfa. ${ }^{11}$

Z roku 1676 a zejména z časového období let 1678 až 1682 se záznamy do Holíkova památníku nedochovaly, další následují až z roku 1683. Mezitím se zřejmě již v roce 1677 Jiří Holík vydal do Königsbergu (Královce, dnes Kaliningrad v Rusku) v tehdejších Vévodských či Východních Prusích, kde se v červenci následujícího roku zapsal na tamější univerzitu. ${ }^{12}$ Získal zde také povolení provádět sbírku a obstarávat si tak prostř̌edky na svou obživu ${ }^{13}$ a zřejmě se v tomto městě narodil i jeden z jeho synů; ${ }^{14}$ následně se pak přesunul do Rigy v tehdy švédském Livonsku. Památník dokládá Holíkův pobyt v Königsbergu až v květnu a červnu 1683 a ke dni 24. května je v něm zapsán lékař a filozof Gottfried Sand (1647 Königsberg - 1720 tamtéž), ${ }^{15}$ který se později stal významnou osobností tamní lékařské fakulty. Kromě studia na univerzitě v rodném městě (1668) studoval krátce rovněž v Kodani, Kielu, Rostocku, Wittenbergu, Helmstedtu a Vídni a zrrejmě díky bohatému mecenáši mohl dále cestovat do Benátek a Padovy, kde se stal magistrem filozofie a v roce 1672 doktorem medicíny. Poté pokračoval ještě dále do Neapole a přes Švýcarsko, Francii,

11 Viz Ernst FriedlaEnder, Aeltere Universitäts-Matrikeln. Universität Greifswald, 2, Leipzig 1894 (Publicationen aus den K. Preußischen Staatsarchiven 57), s. 123, 138, 151, 174; Georg ERLER (ed.), Die jüngere Matrikel der Universität Leipzig 1559-1806, II, Die Immatrikulationen vom Wintersemester 1634 bis zum Sommersemester 1709, Leipzig 1909, s. 173; Dirk Alvermann - Birgit DAhlENBuRG, Greifswalder Köpfe. Gelehrtenporträts und Lebensbilder des 16.-18. Jahrhunderts aus der Pommerschen Landesuniversität, Rostock 2006, s. 94-95.

12 Georg ErLer (ed.), Die Matrikel der Albertus-Universität zu Königsberg i[n] Pr[eussen] 1544-1829, II, Die Immatrikulationen von 1657-1829, Leipzig 1911/12 (Publikation des Vereins für die Geschichte von Ost- und Westpreussen), s. 109 („Geo. Holyk, Michowicen., exul“, 20. 7. 1678); III, Personenregister und Heimatsverzeichnis, Leipzig 1917, s. 614.

13 Alexander Schunka, Migrationen evangelischer Geistlicher als Motor frühneuzeitlicher Wanderungsbewegungen, in: Herman J. Selderhuis - Markus Wriedt (eds.), Konfession, Migration und Elitenbildung: Studien zur Theologenausbildung des 16. Jahrhunderts, Leiden - Boston 2007, s. 1-26, tam s. 12, pozn. 36 (odkaz na Geheimes Staatsarchiv Preußischer Kulturbesitz Berlin-Dahlem, XX. HA, Etats-Ministerium, 43c/31, 39a/6a i pro další duchovní z Čech a Uher).

14 V matrice rižského lycea z let 1675-1709 je k 6. květnu 1687 zapsán „Bernhardus Hollyck, Regiom[ontanus]-Borussus“" - viz Fr[iedrich] Bienemann jun. (ed.), Die Matrikel des Rigaschen Lyceums. 1675-1709, [Mittau] [1902], s. 11. Vzhledem k tomu, že do lycea přicházeli chlapci ve věku od deseti let, odpovídalo by jeho narození právě předpokládanému pobytu Jiřího Holíka v Královci, respektive jeho počátku. První dítě J. Holíka se narodilo ještě v době působení v Barby (viz Marie Ryantová, Konvertita a exulant Jiři Holik. Př́spěvek k dějinám exilu a problematice konverze v raném novověku, Pelhřimov 2016, s. 55) a narození dalšího syna, o jehož kmotrovství J. Holík neúspěšně žádal švédského kancléře Magnuse de la Gardie, připadlo na druhý pobyt ve Stockholmu v roce 1675 (tamtéž, s. 71; dále Riksarkivet Stockholm, De la Gardieska samlingen, sign. E 1614, dopis ze dne 3. 7. 1675; Ilmar TALVE, Georgius Franciscus Holyk: ein Beitrag zur Geschichte der landwirtschaftlichen Literatur des Baltikums im 17. Jahrhundert, Bonn 1955, s. 14, pozn. 22).

15 Staats- und Landesbibliothek Hamburg, Autographensammlung, sign. Cod. 70, s. 456, 1469r: „Gottfridus Sand, Ph. et M. D., P. P., Extraord[inarius]““. 
Holandsko, Anglii a Belgii se v roce 1673 vrátil do Königsbergu. Od následujícího roku působil na lékařské fakultě, kde se postupně stal mimořádným (1682) a řádným (1691) profesorem, od roku 1707 působil jako profesor primarius a senior lékařské fakulty a v zimním semestru 1707/1708 současně i jako prorektor univerzity. ${ }^{16} \mathrm{~V}$ době setkání s Jiřím Holíkem tedy stál Gottfried Sand na počátku své odborné kariéry, během níž se zabýval např́klad diabetem (Dissertatio Academica De Diabete, 1682).

Z Königsbergu, města založeného kdysi na počest Přemysla Otakara II., které v té době bylo metropolí Východních, respektive Knížecích či Vévodských Prus, tvorrících od roku 1618 součást braniborsko-pruského státu pod vládou Hohenzollernů, ${ }^{17}$ pokračoval Jiří Holík přes rovněž pruský Memel (dnes Klaipèda v Litvě) do Kuronska, tehdy samostatného vévodství, kde je doložen od října 1683 do června 1684. Během své návštěvy kuronské metropole Jelgavy (německy Mitau, dnes Lotyšsko) se 21. června 1684 Jiří Holík setkal $\mathrm{s}$ dalším vysoce postaveným lékařem. Byl jím Johann Harder (1635-1692), ${ }^{18}$ který studoval v Königsbergu, Jeně a také Leidenu a poté vykonával praxi v Jelgavě, od roku 1680 byl osobním lékařem kuronského vévody Jakuba a později i jeho nástupce vévody Friedricha Casimira. ${ }^{19}$ Jako lékař byl přitom vysoce ceněn u dvora i v celé zemi (celé Kuronsko mělo tehdy dva lékaře, respektive doktory medicíny), pečoval mj. o vévodu Jakuba během jeho těžké nemoci, připisované očarování úředníka z Neugut Magnuse Luchta, který pak byl v kuronském Bauske veřejně upálen. K Harderovým povinnostem jakožto dvorního lékaře patřilo i zkoušení lékárníků, kteří se usadili v Kuronsku. ${ }^{20}$

Další záznamy lékařủ pocházejí až ze závěru vedení památníku a zřejmě i Holíkova života. Na samém konci roku 1695, 30. prosince, ${ }^{21}$ se v sasko-anhaltském městě Zeitz (tehdy sídle samostatného vévodství) setkal s doktorem medicíny Wilhelmem Zapfiem (1644 Výmar - 1720 Torgau), který byl synem knížecího sasko-výmarského vrchního a dvorního kazatele, generálního superintendenta a asesora vrchní konzistoře, vrchního kazatele

16 Viz Daniel Heinrich ARnold, Ausführliche und mit Urkunden versehene Historie der Königsbergischen Universität, Königsberg in Preußen 1746, 2. Teil, s. 305, 316, 318, 328; Ch. G. JöchER, Allgemeines Gelehrten-Lexicon, Bd. 4, sl. 113; Gustav FRÜH - Hans GOEdEKE - Hans Jürgen von WiLckens, Die Leichenpredigten des Stadtarchivs Braunschweig, Bd. 7, Hannover 1983, s. 3470-3471 (Nr. 5606); Adolph HofmeISTER, Die Matrikel der Universität Rostock, III, (1611-1694), Rostock 1895, s. 240; G. ErLer (ed.), Die Matrikel der Albertus-Universität zu Königsberg i[n] Pr[eussen, II, Die Immatrikulationen von 1657-1829, s. 80.

17 František HonZÁK - Marek PeČEnKA - Jitka VlČKovÁ, Evropa v proménách staletí, Praha 1995, s. 380.

18 Staats- und Landesbibliothek Hamburg, Autographensammlung, sign. Cod. 70, s. 164, 477r: ,Joh[annes] Harder, D[octor] et Seren[issimi] Curlandiae Ducis Archiater".

19 Viz i Marie Ryantová, Česká stopa v Kuronsku - exulant Jiři Holík a jeho kontakty v letech 1683 až 1685, in: Tomáš Jiránek - Karel Rýdl - Petr Vorel (edd.), Gender History - to přece není nic pro feministky. Kniha, kterou napsali přátelé a studenti Mileny Lenderové při př́ležitosti jejího těžko uvěřitelného životního jubilea, Pardubice 2017, s. 83-96.

20 Viz Axel Frey, Baltischer Biographischer Index/Baltic Biographical Index, Bd. 1, München 1999, s. 305, F. 116, 149, dále i Baltisches Biographisches Lexikon digital, http://www.bbl-digital.de/eintrag/Harder-Johann-1635-1692/ (5. 1. 2018); Reinhold JAUERnIG - Marga STEIGER (eds.), Die Matrikel der Universität Jena, II, 1652 bis 1723. Personenregister, Weimar 1961-1977 (Veröffentlichungen der Friedrich-Schiller-Universität Jena), s. 356 (Harder Joh., Düneberga Curonus); Georg ERLER (ed.), Die jüngere Matrikel der Universität Leipzig 1559-1806, II, Die Immatrikulationen vom Wintersemester 1634 bis zum Sommersemester 1709, Leipzig 1909, s. 159 (Harder Ioh. Curland.); G. ERLER (ed.), Die Matrikel der Albertus-Universität zu Königsberg i[n] $\operatorname{Pr}$ [eussen], II, Die Immatrikulationen von 1657-1829, s. 64 (7. 3. 1671 Harder Joh., Düneburg. Curon.); III, Personenregister und Heimatverzeichnis, Leipzig 1917, s. 160.

21 Staats- und Landesbibliothek Hamburg, Autographensammlung, sign. Cod. 70, s. 430, 1402r: „Guilielmus Zapfi[us], S. Sereniss[ismi] [?] Archiater Sereniss[imi] et Reverendiss[imi] Ducis Saxo-Na[m]burg[ensis] Consiliari[us] et Archiater Capituliq[ue] Cistenser Canonic[us]". 
v kostele sv. Petra a Pavla ve Výmaru Nicolause Zapfia (1600-1672) a v Zeitz působil jako knížecí saský dvorní a osobní lékar̆.22

O dva měsíce později Jiř́ Holík znovu pobýval v jemu známém Wittenbergu a 5. března 1696 se zde setkal s lékařem Christianem Vaterem (1651 Jüterbog - 1732 Wittenberg). ${ }^{23}$ Ten studoval na univerzitě ve Wittenbergu nejprve filozofii (1675 magistr), poté se věnoval medicíně (1679 licenciát medicíny - s disputací o melancholii, 1681 doktorát). Když se usadil ve Wittenbergu jako lékar̆, bylo mu v roce 1682 dovoleno veřejně disputovat, o čtyři roky později se stal zemským fyzikem, $v$ roce 1690 mimořádným a o dva roky později rádným profesorem lékařství, v roce 1695 druhým rrádným profesorem, $\mathrm{v}$ zimních semestrech 1695/1696 (tj. v době, kdy jej navštívil Jiří Holík) a 1701/1702 byl rektorem a v zimním semestru 1707/1708 prorektorem wittenberské univerzity. Zabýval se zejména fyziologií, byl autorem díla Physiologia experimentalis et demonstrativa iconibus illustrata (Wittenberg, 1701, 1712). Rovněž on se řadil mezi osobní lékaře významných osobností - v jeho prípadě knížete von Anhalt-Zerbst. Pod jménem „Nicomachus“ byl Christian Vater členem již zmíněné Leopoldinské akademie (Academia Naturae Curiosorum). ${ }^{24}$

Posledním lékařem, zachyceným v památníku Jiř́ho Holíka, je Heinrich Meibom (i Meibaum) (1638 Lübeck - 1700 Helmstedt), doktor medicíny, profesor a senior lékařské fakulty na univerzitě v Helmstedtu, současně brunšvicko-lüneburský knížecí rada a osobní lékař; Jiří Holík se s ním setkal právě v Helmstedtu 20. května 1697. ${ }^{25}$ Heinrich Meibom byl synem profesora medicíny v Helmstedtu, kde sám začal v roce 1655 studovat, poté pokračoval na univerzitě v Groningen (1659) a v letech 1660-1661 navštěvoval významné profesory na univerzitách ve Franekenu, Leidenu, Amsterodamu, Haagu a Utrechtu. Po návratu se stal mimořádným profesorem v Helmstedtu, ale vzápětí absolvoval další cestu do jižního Německa a Itálie, kde navštívil Bolognu, Řím, Padovu, Florencii a Ferraru, nazpět se vydal přes Francii (Lyon, Paris, Orleans, Saumur, Angers - tam získal v roce 1663 doktorát), Anglii (London, Oxford, Canterbury) a Holandsko. Po audienci u vévody Augusta z Braunschweigu a Lüneburgu byl jmenován jeho osobním lékařem a od roku 1664 byl profesorem medicíny v Helmstedtu, v roce 1678 se navíc stal i profesorem historie a poezie, stejně jako kdysi jeho dědeček Heinrich Meibom starší. Celkem dvanáctkrát byl zvolen děkanem lékařské fakulty a sedmkrát prorektorem. Věnoval se převážně anatomii, fyziologii a chirurgii, je autorem padesáti sedmi lékařských pojednání a objevitelem jednak mazových žlázek $\mathrm{v}$ očních víčkách, které po něm dostaly název (Meibomovy či meibomské žlázky, latinsky Glandulae tarsales Meibomii), jednak slepého otvoru v jazyce (Foramen

22 Viz Gustav FrüH - Hans Goedeke - Hans Jürgen von Wilckens, Die Leichenpredigten des Stadtarchivs Braunschweig, Bd. 9, Hannover 1985, s. 4553 (Nr. 7412); Zapf, (Wilhelm), in: J. H. ZedLer, Grosses vollständiges Universal-Lexicon Aller Wissenschafften und Künste, Bd. 60, Leipzig 1749, sl. 1623-1624.

23 Staats- und Landesbibliothek Hamburg, Autographensammlung, sign. Cod. 70, s. 451, 1456r: „Christian Vater, Acad[emiae] Rector“.

24 Viz Vater, Christian, in: J. H. ZEDLER, Grosses vollständiges Universal-Lexicon Aller Wissenschafften und Künste, Bd. 46, Leipzig 1745, sl. 728-732; Ch. W. Kestner, Medizinisches Gelehrten-Lexikon, s. 881; Julius PAgel, Vater, Christian, in: Allgemeine Deutsche Biographie, Bd. 39, Leipzig 1895, s. 503; F. JuntKe (ed.), Album Academiae Vitebergensis. Jüngere Reihe, Teil 2, 1660-1710, s. 595-596, dále s. 106 (Vater Christianus, Jüterborga Saxo 9. 5. 1674, Mag. phil. 14. 10. 1675, Lic. med. 1679, Doct. med. 8. 11. 1681, Prof. 13. 3. 1692).

25 Staats- und Landesbibliothek Hamburg, Autographensammlung, sign. Cod. 70, s. 258, 779r: „Henricus Meibomius, Med[icinae] D[octor] ejusq[ue] et Historiar[um] Prof[esor] Ordinar[ius] Fac[ultatis] Medicae Senior, Seren[issimi] [?] Ducum Bruns[vicensis] et Lyn[eburgensis] Archiater et h[oc] t[empore] Academiae Juliae ProRector". 
Meibomii). Patřil také k zastáncům Harveyovy teorie krevního oběhu a prováděl v tomto směru různá zkoumání. Kromě lékařských pojednání však psal i latinské verše a vydal je spolu s básněmi svého dědečka (Parodiarum horatianarum libri III et sylvarum libri II, 1588) v díle Scriptores rerum germanicarum tomi III (1688), zabýval se také dějinami Dolního Saska, numismatikou či dějinami dolování. ${ }^{26}$

V rámci Holíkova památníku, který obsahuje záznamy nejrůznějších osobností, mezi nimiž převažují především různí teologové či pastoři, ale nechybějí ani některé mnohdy i proslulé postavy politického života, představují záznamy uvedených devíti lékařů velmi zajímavou, i když nijak zvlášt’ početnou skupinu (jedná se o zhruba čtyři procenta všech záznamů). Památník Jiř́ho Holíka je ovšem jak rozsahem, tak spektrem záznamů výjimečný, zejména s přihlédnutím k osobě majitele jakožto exulanta. Pokud jsou dochovány podobné rukopisy patřící osobám z řad exulantů, odrážejí spiše jejich vazby k nejbližšímu okolí, a to jak ve smyslu teritoriálním, tak ideovém či společenském, zatímco Jiří Holík alespoň některé tyto hranice výrazně překračoval. Vzhledem k charakteru památníku i k Holíkovým osudům lze předpokládat, že získávání záznamů pro něj mělo - stejně jako v řadě jiných př́padů - především sběratelský charakter a bylo otázkou sebeprezentace a prestiže (proto se snažil získat podpisy významných osobností), př́ípadně mohlo být doplněno i debatami na různá témata, nejspíše se však s ohledem na postavení a funkce zapsaných osob nejednalo o návštěvy za účelem lékařského vyšetření. O vlastním průběhu získávání záznamů sice nejsou k dispozici dostatečné informace, lze však předpokládat, že ani pro majitele památníku, ani pro zapisovatele nejspíše setkání s tím spojené obvykle neznamenalo žádný odborný prrínos (zvláště u uvedených lékařských záznamů), ale představovalo ryze společenskou záležitost. Přesto jsou pro nás zápisy více či méně proslulých lékařů v Holíkově památníku cenným dokladem působení a zejména kontaktů jedné ze zajímavých postav českého exilu, kterých se jeho domácím současníkům zřejmě nikdy nedostalo.

26 Viz G. FrüH - H. Goedeke - H. J. von Wilckens, Die Leichenpredigten des Stadtarchivs Braunschweig, Bd. 5, Hannover 1981, s. 2481-2483 (Nr. 4075); Sabine Ahrens, Meibom, Heinrich (d. J.), Dr. med., Prof, in: Horst-Rüdiger Jarck - Dieter Lent u. a. (edd.), Braunschweigisches Biographisches Lexikon. 8. bis 18. Jahrhundert, Braunschweig 2006, s. 487; Meibom, Heinrich, der jüngere, in: J. H. ZEDLER, Grosses vollständiges Universal-Lexicon Aller Wissenschafften und Künste, Bd. 20, Leipzig 1739, s1. 280-282; Viktor von MEIвом, Meibom, Heinrich, in: Allgemeine Deutsche Biographie, Bd. 21, Leipzig 1885, s. 187an; Peter JoHANEK, Meibom, Heinrich, in: Neue Deutsche Biographie, Bd. 16, Berlin 1990, s. 631; Werner Hillebrand (ed.), Die Matrikel der Universität Helmstedt 1636-1685, Hildesheim 1981, s. 111 (13.9. 1655 Meibomius Henricus, Lubecensis); Herbert Mundhenke (ed.), Die Matrikel der Universität Helmstedt 1685-1810, Hildesheim 1979, s. 46 . 
Příloha: Přehled lékařủ zapsaných v památníku Jiřího Holíka

\begin{tabular}{|c|c|c|c|c|c|c|}
\hline Č́́slo & Rok & Datum & Místo & Záznam & Jazyk & Citace \\
\hline 1. & 1673 & 2.4 . & $\begin{array}{l}\text { Witteb[ergae] } \\
\text { [Wittenberg] }\end{array}$ & $\begin{array}{l}\text { Conradus Victor Schneider, } \\
\text { Sereniss[imi] Elect[oris] Saxon[niae] } \\
\text { Med[icus] Etc. }\end{array}$ & $\mathrm{Lv}, \mathrm{s}$ & $\begin{array}{l}\text { Cod. } 70 \text {, } \\
\text { s. } 453,1462 \mathrm{v}\end{array}$ \\
\hline 2. & 1673 & $\begin{array}{l}\text { Mens[e] } \\
\text { April[is] }\end{array}$ & $\begin{array}{l}\text { Wittebergae } \\
\text { [Wittenberg] }\end{array}$ & Michael Sennertus, D. P. P. & $\mathrm{Lv}, \mathrm{s}$ & $\begin{array}{l}\text { Cod. } 70, \\
\text { s. } 454,1463 \mathrm{v}\end{array}$ \\
\hline 3. & $\begin{array}{l}\text { s. d. } \\
{[1674 ?]}\end{array}$ & & $\begin{array}{l}\text { Rostochii } \\
\text { [Rostock] }\end{array}$ & $\begin{array}{l}\text { Sebastianus Wirdig, Med[icinae] D] } \\
\text { octor], olim in Regia Liv[landiae] } \\
\text { Dorpatensi, nunc in illustro } \\
\text { Rostochiensi Acad[emia] Prof[esor] } \\
\text { et Medicus Ducalis }\end{array}$ & $\mathrm{Lv}, \mathrm{s}$ & $\begin{array}{l}\text { Cod. } 70, \\
\text { s. } 453,1462 \text { r }\end{array}$ \\
\hline 4. & 1674 & 20.5 & $\begin{array}{l}\text { Gryphiswaldis } \\
\text { [Greifswald] }\end{array}$ & $\begin{array}{l}\text { Christophorus Helvigius, Doct[or] et } \\
\text { Prof[esor] Medic[inae] ordinar[ius] } \\
\text { Acad[emiae] h[oc] t[empore] Rector }\end{array}$ & $\begin{array}{l}\text { Lv, ̌rs, } \\
\text { Ls,Lsy }\end{array}$ & $\begin{array}{c}\text { Cod. } 70, \\
\text { s. } 170,499\end{array}$ \\
\hline 5. & 1683 & 24.5 . & $\begin{array}{l}\text { in Acad[emia] } \\
\text { Regiomontana } \\
\text { [Královec, } \\
\text { dnes Rusko] }\end{array}$ & $\begin{array}{l}\text { Gottfridus Sand, Ph. et M. D., P. P., } \\
\text { Extraord[inarius] }\end{array}$ & $\mathrm{Lv}, \mathrm{s}$ & $\begin{array}{l}\text { Cod. } 70, \\
\text { s. } 456,1469 \mathrm{r}\end{array}$ \\
\hline 6. & 1684 & 21.6 & $\begin{array}{l}\text { Mÿtaviae } \\
\text { [Mittau, } \\
\text { dnes Jelgava, } \\
\text { Lotyšsko] }\end{array}$ & $\begin{array}{l}\text { Joh[annes] Harder, D[octor] et } \\
\text { Seren[issimi] Curlandiae Ducis } \\
\text { Archiater }\end{array}$ & $\mathrm{Lv}, \mathrm{s}$ & $\begin{array}{c}\text { Cod. } 70, \\
\text { s. } 164,477 \mathrm{r}\end{array}$ \\
\hline 7. & 1695 & 30.12. & $\begin{array}{l}\text { Cistae } \\
{[\text { Zeitz] }}\end{array}$ & $\begin{array}{l}\text { Guilielmus Zapfi[us], S. } \\
\text { Sereniss[ismi] ...cis ad. Archiater } \\
\text { Sereniss[imi] et Reverendiss[imi] } \\
\text { Ducis Saxo-Na[m]burg[ensis] } \\
\text { Consiliari[us] et Archiater } \\
\text { Capituliq[ue] Cistenser Canonic[us] }\end{array}$ & $\mathrm{Lv}, \mathrm{s}$ & $\begin{array}{l}\text { Cod. } 70, \\
\text { s. } 430,1402 \text { r }\end{array}$ \\
\hline 8. & 1696 & 5.3. & Wittenberg & Christian Vater, Acad[emiae] Rector & $\mathrm{Lv}, \mathrm{s}$ & $\begin{array}{l}\text { Cod. } 70 \\
\text { s. } 451,1456 \mathrm{r}\end{array}$ \\
\hline 9. & 1697 & 20.5 . & $\begin{array}{l}\text { Helmstadii } \\
\text { [Helmstedt }]\end{array}$ & $\begin{array}{l}\text { Henricus Meibomius, Med[icinae] } \\
\text { D[octor] ejusq[ue] et Historiar[um] } \\
\text { Prof[esor] Ordinar[ius] Fac[ultatis] } \\
\text { Medicae Senior, Seren[issimi] } \\
\text { ? Ducum Bruns[vicensis] et } \\
\text { Lyn[eburgensis] Archiater et } \\
\text { h[oc] t[empore] Academiae Juliae } \\
\text { ProRector }\end{array}$ & $\mathrm{Lv}, \mathrm{s}$ & $\begin{array}{c}\text { Cod. } 70, \\
\text { s. } 258,779 \mathrm{r}\end{array}$ \\
\hline
\end{tabular}

Vysvětlivky k príloze:

Číslo Pořadové číslo zápisu.

Rok Rok vzniku zápisu.

Datum Datum vzniku zápisu. V̌̌echna data byla převedena na současný způsob, at’ už byla v originále uvedena jakkoli.

Místo Místo vzniku záznamu, a to v podobě, v jaké se nachází v památníku (transliterace), včetně př́padného upřesnění (in Academia). Současný název je uveden v závorce. 
Záznam Informace o inskribentovi: je uvedeno křestní jméno a př́imení, a to v podobě, v jaké se nachází v památníku (transliterace). Připojeny jsou i případné další významné informace, tvořící součást záznamu, jiné byly doplněny v poznámce pod čarou.

Jazyk Jazyk, jímž je záznam psán - tj. věnování a př́padné sentence: $L$ - latina, $\breve{\mathrm{R}}$ - řečtina; v = věnování; $\mathrm{s}=$ sentence; sy = symbola.

Citace Odkaz na zdroj.

\title{
MARIE RYANTOVÁ
}

\section{Der Emigrant Jiří Holík und seine Kontakte zu Ärzten in den deutschen Ländern und im Baltikum}

\author{
ZUSAMMENFASSUNG
}

Eine der interessanten Gestalten des tschechischen Exils ist Jiří Holík (1635-1700/1710?), ursprünglich Dominikaner, der seine Heimat verließ, zum Luthertum konvertierte und als Prediger tschechischer Emigranten tätig war. Bald jedoch musste er seine Stelle verlassen und erlangte schließlich als Autor von Schriften über Gartenbau und Obstbau Berühmtheit und zählt bis heute zu den bedeutenden und anerkannten Persönlichkeiten der europäischen Obstbaukunde (Pomologie) des 17. Jahrhunderts. Bereits ab 1673 und insbesondere von 1683 bis 1698 unternahm er zahlreiche Reisen, auf denen er seine Bücher verkaufte bzw. verteilte und mittels ihrer um Unterstützung bat. Später widmete er sich auf seinen Reisen auch gärtnerischen Tätigkeiten und verarbeitete die dabei gewonnenen Erfahrungen anschließend in weiteren Büchern. Ein wertvolles Zeugnis von diesen Reisen, auf denen er mit den verschiedensten Persönlichkeiten zusammentraf, sind die Notizen in seinem Stammbuch, das sich nur torsohaft in Gestalt einiger loser Blätter erhalten hat. Dennoch enthält es die respektable Zahl von 226 Eintragungen. Autoren der meisten Einträge waren verschiedene Pastoren und Superintendenten, Theologen, Juristen, kurfürstliche Räte und Beamte, aber auch Universitätsprofessoren oder Rektoren. Unter den Eintragungen befinden sich auch die von neun bedeutenden Ärzten der Jahre 1673 bis 1697, die an den Universitäten in Wittenberg, Rostock, Greifswald, Königsberg und Helmstedt tätig waren oder (und mitunter gleichzeitig) als Leibärzte verschiedener Herrscher wirkten (beispielsweise des Herzogs von Kurland, des sächsischen oder brandenburgischen Kurfürsten, des mecklenburgischen oder braunschweig-lüneburgischen Herzogs). Der Charakter des Stammbuches und Holíks Schicksal lässt die Annahme zu, dass die Einträge für ihn vor allem Sammelcharakter hatten und eine Frage der Selbstpräsentation und des Prestiges darstellten, gegebenenfalls auch durch Debatten zu verschiedenen Themen ergänzt werden konnten. Sicherlich handelte es sich hierbei jedoch weder um Besuche zwecks ärztlicher Untersuchung noch um ärztliche Konsultationen. Trotzdem stellen diese Vermerke einen wertvollen Beleg für Kontakte einer interessanten Gestalt des tschechischen Exils dar.

Deutsche Übersetzung Wolf B. Oerter

\author{
Marie Ryantová \\ Ústav archivnictví a pomocných věd historických, \\ Filozofická fakulta Jihočeské univerzity v Českých Budějovicích \\ ryantova@ff.jcu.cz
}

